\title{
Review Article \\ Study on Calculation Models of Earth-Air Heat Exchanger Systems
}

\author{
Trilok Singh Bisoniya, Anil Kumar, and Prashant Baredar \\ Energy Centre, Department of Mechanical Engineering, Maulana Azad National Institute of Technology, Bhopal 462051, India \\ Correspondence should be addressed to Trilok Singh Bisoniya; tsbisoniya@gmail.com
}

Received 12 May 2014; Accepted 11 July 2014; Published 4 September 2014

Academic Editor: Mohamed Benghanem

Copyright ( 2014 Trilok Singh Bisoniya et al. This is an open access article distributed under the Creative Commons Attribution License, which permits unrestricted use, distribution, and reproduction in any medium, provided the original work is properly cited.

\begin{abstract}
Modeling is very useful tool in order to predict the effect of the operating parameters like pipe length, radius, depth of burial and air flow rate on the thermal performance and heating/cooling capacity of earth-air heat exchanger (EAHE) systems. Till date many researchers have carried out a number of studies on calculation models for earth-air heat exchanger systems. The analysis of EAHE systems started with the development of one-dimensional models. The two-dimensional models came into practice during the 1990s and were replaced by three-dimensional models in recent years. Latest models are dynamic and technically more advanced which can provide room for all types of grid geometry to produce detailed thermal analysis of EAHE systems. This paper reviews on calculation models of EAHE systems as of the end of March, 2014.
\end{abstract}

\section{Introduction}

The present world energy scenario indicates that the conventional energy sources are depleting and per capita energy consumption is indication of living standard of a nation so, it becomes very important to find and explore nonconventional energy sources to meet the energy requirement of the society. The nonconventional energy sources are better option of clean and sustainable energy. This kind of energy is, at principle, inexhaustible and can be found and exploited equally well on the planet [1]. Nowadays, air conditioning is commonly used in buildings, residential places, offices as well as in industries to achieve comfort conditions. The conventional air conditioners working on vapor compression refrigeration cycle are effective and most widely used means to achieve comfort conditions. The chlorofluorocarbons (CFCs) which are used as refrigerants in these machines result in depletion of the ozone layer and global warming. In order to save our planet from hazardous effects of UV rays by minimizing depletion of the ozone layer, the world scientific community has developed eco-friendly refrigerants. To minimize depletion of the ozone layer and global warming and to reduce high grade energy consumption, numerous alternative techniques are being currently explored $[2,3]$. One of the promising techniques is earth-air heat exchangers.

It is seen that the temperature of ground at a depth of about 1.5 to $2 \mathrm{~m}$ remains constant around the year and is equal to the annual average temperature of a particular locality. This constant temperature (earth's undisturbed temperature) remains lower than ambient temperature in summer season and vice versa in winter. The earth-air heat exchanger (EAHE) is basically a series of metallic, plastic or concrete pipes buried underground at a particular depth through which the fresh atmospheric air flows and gets cooled in summer and vice versa in winter. It is a device which utilizes heat capacity of earth effectively. The soil at the depth of burial of pipes of EAHE acts as heat source in winter and as sink in summer for air which is used as heat transfer medium in the system. The EAHE system can effectively meet the heating/cooling requirement of the building if the temperature of air at outlet of the system is sufficiently high/low enough. Otherwise, additional heating/cooling of the outlet air may be achieved by passing it through the conventional air conditioners. The EAHE used in either way can result in reduction of high grade energy consumption. Many researchers have denoted 
that the earth-air heat exchangers (EAHEs) connected with buildings are effective and passive energy source for space conditioning of buildings [4-6]. The behavior of an EAHE system is mainly affected by surface conditions, temperature, and moisture distribution in the ground [7].

The classification of site for installation of EAHEs was done on the basis of geological properties of particular location. The information of physical and thermal properties of soil (diffusivity, density, thermal conductivity, etc.), depth to water, depth of bedrock, and type of soil guides the designer in choosing correct type of EAHE system and in the design of the system [8-16]. The EAHE systems were mainly classified as open loop EAHE and closed loop EAHE system. In open loop EAHE system, fresh ambient air is drawn through buried pipes which gets moderated to the earth's undisturbed temperature and finally is supplied to the building to meet the heating/cooling requirement of the building as shown in Figure 1 while in closed loop EAHE system recirculation of the air from building through the buried pipes is done as shown in Figure 2.

The closed loop EAHE system is not preferred over open loop EAHE system because it does not meet the building's fresh air requirement.

One of the major reasons behind nonrecognition of EAHE systems even today is lack of knowledge of how to design an efficient system besides the other disadvantages related to them like poor air quality with prolonged use, higher setup cost, growth of harmful microorganisms, and so forth. The need of the hour is to generalize the use of EAHE systems so that the use of renewable and sustainable energy technologies can be promoted. This paper aims to review the current state of the art regarding calculation models of EAHE systems by going through research publications in scientific journals and conferences.

The structure of the paper is as follows. The first section includes the introductory part; studies conducted on calculation models of EAHE systems including one-dimensional models, two-dimensional models, and three-dimensional models are investigated in the second section, and the last section concludes.

\section{Studies Conducted on Calculation Models of EAHE Systems}

The parameters like pipe material, length of pipe, diameter of pipe, spacing between pipes, number of pipes, soil type, depth of burial, and air flow rate are mainly considered for proper designing of effective EAHE system. The EAHE system if properly designed can be feasible and economical option to replace conventional air-conditioning systems as there is no need of compressors, burners, or chemicals and only blowers are required to move the air. The EAHE systems have many advantages over other passive heating/cooling techniques. The main advantages include minimized air pollution, higher COP, simpler design, low maintenance, and operational costs [17]. In the last two decades, a lot of research has been done to develop analytical and numerical models for analysis of EAHE systems. The performance analysis of EAHE involved either the calculation of conductive heat transfer from the pipe to the ground mass or the calculation of convective heat transfer from the circulating air to the pipe and changes in the air temperature and humidity.

A number of computer modeling tools are commercially available. EnergyPlus and TRNSYS have EAHE modules that work well; however these are analysis tools and are not quickly used for design. Presently, computational fluid dynamics (CFD) is very popular among researchers for modeling and performance analysis of EAHE systems because the CFD employs a very simple rule of discretisation of the whole system in small grids and governing equations applied on these discrete elements to get numerical solutions concerning flow parameters, pressure distribution, and temperature gradients in less time and at reasonable cost because of reduced required experimental work [18, 19]. Many other papers on different design methods of EAHE systems have been published. As the one-dimensional heat conduction problem is simple and fast to give results, the majority of papers were based on discretisation of one-dimensional heat transfer problem in the pipes. Two-dimensional and threedimensional models which are more dynamic and complex in nature were also found but not found suitable for being ready to use by designers.

The EAHEs mainly find their applications in greenhouses, livestock houses, commercial and residential buildings, and so forth for space conditioning. The various researchers made different assumptions for modeling and writing energy balance equations for EAHE systems. The major hypothesis made by researchers for modeling of EAHE systems connected to greenhouses includes the following.

(i) The greenhouse is in a quasisteady-state condition [20-24].

(ii) Radiative heat exchange between the greenhouse walls and the roof is neglected due to its small value $[20,22,24]$.

(iii) Relative humidity inside the greenhouse does not vary with height [21].

(iv) Specific heat of plants in the greenhouse has been taken to be the same as that of water [20,21].

(v) Heat capacity of air inside the greenhouse is neglected $[20,21]$.

(vi) Flow of air is uniform along the length of buried pipes $[22,24]$.

(vii) There is no radiative heat exchange between the sides of the buried pipe $[22,25]$.

(viii) The heat extraction does not disturb the temperature distribution of the surrounding earth [22].

(ix) Depth of immersion is constant throughout the whole length of the trench [20].

The assumptions generally considered for modelling and thermal performance analysis of EAHE systems used for heating/cooling applications of buildings are as follows.

(i) The pipe used in EAHE is of uniform cross section [26]. 
(ii) The thermal resistance of pipe material is negligible (thickness of pipe is very small) [26].

(iii) The soil surrounding the pipe is isotropic, with homogenous thermal conductivity in all ground strata [26-28].

(iv) Thermal effect of soil surrounding the pipe is negligible after a distance " $r$ " from the pipe outer surface, where " $r$ " is the pipe radius [26].

(v) There is no evaporation or freezing in soil; vapor and air in the pore space are assumed to be ideal gases [26, 27].

(vi) The effect of moisture condensation on the cooling capacity of EAHE can be ignored especially when the dew point temperature of air at inlet of EAHE is higher than the lowest temperature of air along the pipe system (generally the lowest temperature occurs at the pipe outlet) [29].

(vii) Pressure in the soil is considered to be atmospheric [23].

(viii) The surface temperature of the ground can be approximated to the ambient air temperature, which equals the inlet air temperature $[26,27]$.

(ix) The temperature profile in the pipe vicinity is not affected by the presence of the pipe. As a result, the pipe surface temperature is uniform in the axial direction [30].

(x) Solar radiation is assumed to be constant [27].

(xi) Possible latent heat exchanges are not accounted for, which means that no water infiltration is at work and that the air temperature is supposed to remain above its dew point $[27,28]$.

The studies conducted oncalculation models of EAHE systems are divided into three categories, namely, onedimensional models of EAHE systems, two-dimensional models of EAHE systems, and three-dimensional models of EAHE systems.

2.1. One-Dimensional Models of EAHE Systems. Modeling is very useful tool in order to predict the effect of the operating parameters like pipe length, radius, depth of burial, and air flow rate on the thermal performance and heating/cooling capacity of EAHE systems. Till date many researchers have carried out a number of studies on calculation models for earth-air heat exchanger systems. The analysis of EAHE systems started with the development of one-dimensional (1D) models. In one-dimensional model the description of the pipe to derive a relation between its inlet and outlet temperature was used. Tzaferis et al. studied eight models [31]. It was found that all these models gave approximately the same results. This indicated that performance of the earth-air heat exchangers may be characterized by a steady-state onedimensional model. Mihalakakou et al. [32], Bojic et al. [33], Ghauthier et al. [34], and Hollmuller and Lachal [35] have published papers on more complete and dynamic models for earth-air heat exchangers.

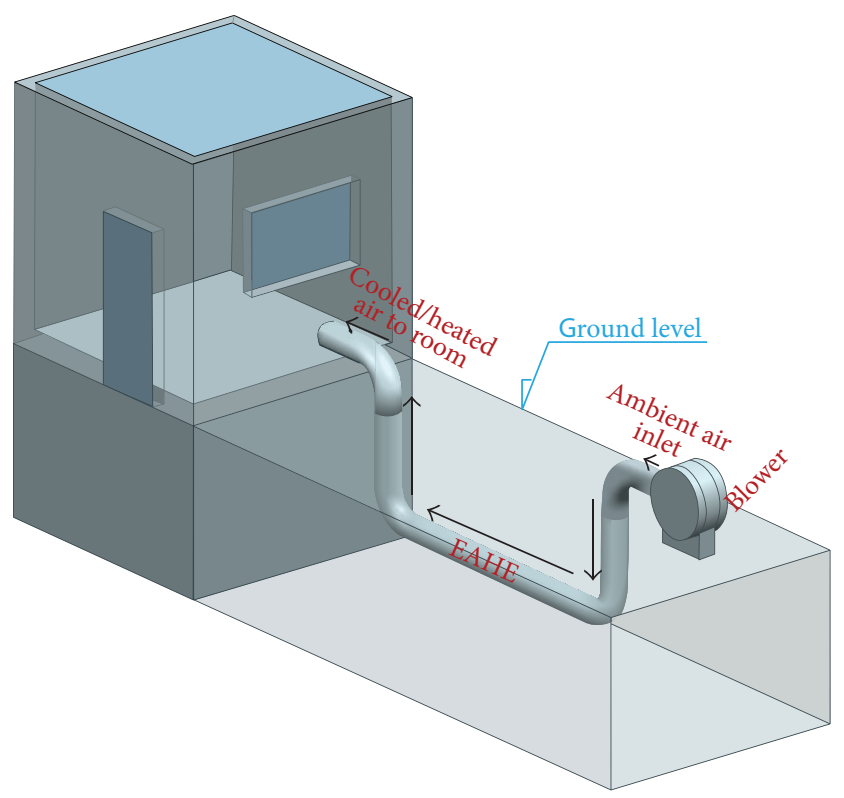

FIGURE 1: Open loop earth-air heat exchanger.

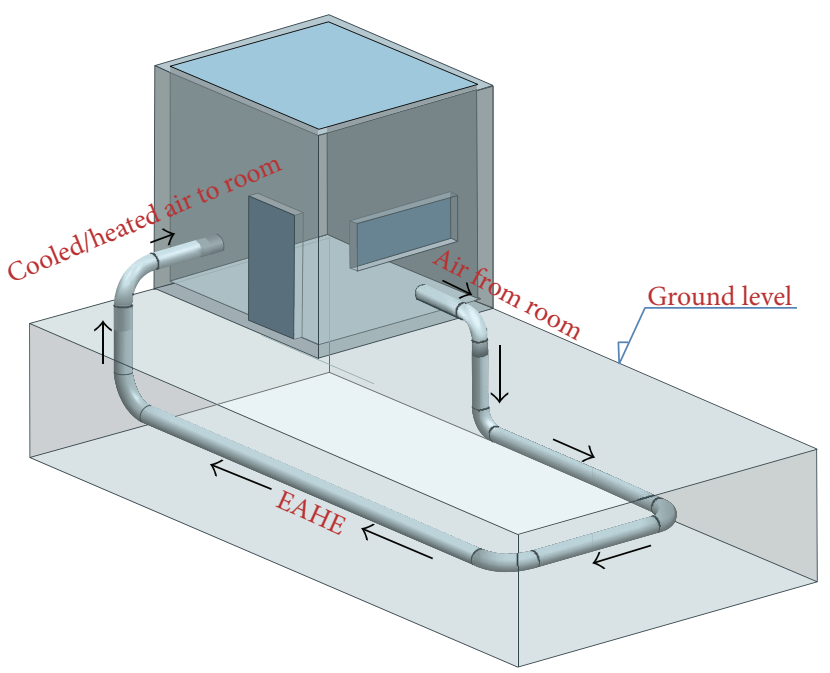

FIGURE 2: Closed loop earth-air heat exchanger.

Kabashnikov et al. [36] presented an effective mathematical model for calculating the temperature of the ground and air in a ground heat exchanger for ventilation systems. The model was based on the representation of temperature in the form of the Fourier integral. Parametric study was performed to analyse performance behaviour of EAHE by taking into account the air flow rate, variation in length, diameter of tubes, depth of burial, and spacing between tubes. The results of calculations agreed with the experimental data. The developed model was simple and easy to calculate and can be referred for design considerations.

Santamouris et al. [37] presented a new integrated method to calculate the contribution of the earth-to-air heat exchangers to the cooling load of the buildings. The method was based on the principle of balance point temperature 
and permitted the calculation of the hourly value of the balance temperature of the building as well as the daily cooling load and the contribution of the buried pipes. An extensive validation procedure has been followed using data from an extended version of TRNSYS which includes detailed routines to simulate dynamically the performance of earthto-air heat exchangers. It was found that the method is of sufficient accuracy and, therefore, can be used during the predesign and design phase for the dimensioning of the buried pipes.

In order to predict the variation of the ground surface temperature for bare and short-grass covered soil Mihalakakou et al. [38] developed a mathematical model based on heat conduction equations and on the energy balance at the ground surface. The model showed very good agreement between the measured and predicted temperature values of two extensive sets of experimental data for Athens and Dublin. It was concluded that the model can predict ground temperature at the surface and at various depths with sufficient accuracy as predicted by other models based on Fourier analysis.

Ben Jmaa Derbel and Kanoun [39] presented a mathematical model predicting the subsurface soil temperature of the region of Sfax, Tunisia, and validated it by measured ground temperatures. An earth fluid pipe model has been developed. Then, the subsurface temperature model has been used in conjunction with the earth fluid pipe model to predict the energy transfer performance. Effects of the earth fluid pipe depth, radius, and length have been investigated. The earthair-pipe model has been validated against the experimental study done by Thanu et al. [40]. The validation process showed that the proposed model agreed with experimental results with respect to the given input parameters.

Ozgener et al. [41] presented an improved model for predicting daily soil temperatures depending on depth and time. Transient heat flow principles were used with assumptions of one-dimensional heat flow, homogeneous soil, and constant thermal diffusivity. Measured and predicted soil temperatures at depths $5 \mathrm{~cm}, 10 \mathrm{~cm}$, and $300 \mathrm{~cm}$ were compared with experimental field results to validate the accuracy of the proposed model. For an annual cycle, at depths of $5,10,20$, and $300 \mathrm{~cm}$, the average maximum percentage of errors was $10.78 \%, 10 \%, 10.26 \%$, and $14.95 \%$, respectively. For more accurate predictions of performance, the use of measured daily soil surface temperatures instead of daily air temperatures and measured soil thermal diffusivities should be used if such data sets are available.

Ghosal et al. [25] developed a complete numerical model to predict and compare thermal performance of two buried pipe systems, that is, ground air collector and EAHE, integrated with the greenhouse located in the premises of Indian Institute of Technology Delhi, India, for choosing a suitable heating method in the composite climate of India. It was concluded that the temperatures of greenhouse air with ground air collector were observed to be $2-3^{\circ} \mathrm{C}$ higher than those with EAHE and the temperature fluctuations of greenhouse air were also less when operated with ground air collector as compared to EAHE. A fair agreement was observed between predicted and computed values of greenhouse air temperatures in both systems. Finally ground air collector was chosen as a suitable option for heating of greenhouse in the composite climate of India.

$\mathrm{Su}$ et al. [42] developed a numerical simulating model for the deeply buried air-earth- (rock-) tunnel system, in which a 1D implicit transient convection-diffusion submodel describes the air temperature and humidity, and a 1D transient explicit heat conduction submodel computes the rock temperature. The accuracy of this numerical model has been verified by comparisons of temperatures of the air and rock and the relative humidity between numerical results and the test data. The maximum error of the air temperature is $1.4^{\circ} \mathrm{C}$ and the maximum error of the relative humidity is $10 \%$ in most cases.

Sehli et al. [43] proposed a one-dimensional numerical model to check the performance of EAHEs installed at different depths. The effects of Reynolds number, installation depth, and form factor on the performance of an earth-toair heat exchanger (ETHE) system were investigated through the parametric analysis. The form factor was defined as the ratio of length of pipe to diameter of pipe. It was observed that with increase in installation depth and form factor the outlet air temperature decreases while with increase in Reynolds number the outlet air temperature increases. Finally, they concluded that EAHE systems alone are not sufficient to create thermal comfort but can be used to reduce the energy demand in buildings in south Algeria, if used in combination with conventional air-conditioning systems.

Kumar et al. [44] developed a transient implicit numerical model based on coupled simultaneous heat and mass transfer equations to describe the thermal performance of EAHE system. The numerical model incorporates greater number of parameters than the previous models, such as humidity variations of circulating air, natural thermal stratification of the ground, latent and sensible heat transfer, and ground surface conditions. The model was developed within the scope of numerical techniques of finite-difference and FFT (MAT$\mathrm{LAB})$. The results indicated very good agreement between the measured results and model predictions. The minor error in the range of $\pm 1.6 \%$ was observed between simulated and experimental data. The present model can be easily coupled to different greenhouse and building simulation codes.

De Paepe and Janssens [45] presented a one-dimensional analytical method to analyze the influence of the design parameters of the heat exchanger on thermohydraulic performance. Three dimensions have to be determined: tube length, tube diameter, and number of parallel tubes. Thermal performance and pressure drop both grow with length. Smaller tube diameters give better thermal performance but also larger pressure drop. More tubes in parallel both lower pressure drop and rise thermal performance. A relation was derived for specific pressure drop, linking thermal effectiveness with pressure drop of the air inside the tube. The relation was used to formulate a design method which can be used to determine the characteristic dimensions of the earth-air heat exchanger in such a way that optimal thermal effectiveness was reached with acceptable pressure loss. The choice of characteristic dimensions became thus independent of the soil and climatological conditions. This allowed designers to 
choose the earth-air heat exchanger configuration with the best performance.

Hollmuller [28] presented the complete analytical solution for the heat diffusion of a cylindrical air/soil heat exchanger with adiabatic or isothermal boundary condition, submitted to constant airflow with harmonic temperature signal at input. Analytical results were validated against a finite-difference numerical simulation model and against an experimental setup. Cucumo et al. [46] approximated the performance behavior of EAHEs buried at different depths. With suitable assumptions, the model permitted calculating the length and humidity ratio at the outlet section of a buried pipe at different depth of installation and to evaluate the performance of a buried pipe of assigned length. The model was developed by the solution of heat and mass balances for air through the buried pipe, taking into account a suitable temperature profile in the ground. This was determined by two methods: the first is based on Green's functions and the second, simplified, was based on the principle of superposition. A very satisfactory agreement was observed between the numerical and the experimental data.

Pfafferott [17] presented a paper which deals with the performance of three EAHXs for mid-European office buildings in service, with the aim of characterizing their efficiency. A general method to compare EAHEs in operation was introduced. First, the temperature behavior was described by plots over time and characteristic lines and compared by standardized duration curves. Second, the energy gain was illustrated by standardized graphs. Third, a parametric model was used to provide general efficiency criteria. Thermal efficiency should be defined by both the dynamic temperature behavior and the energy performance. An important characteristic for passive cooling applications was the temperature ratio $\mathrm{RT}$ which described the temperature damping between inlet and outlet temperature. The smaller RT implied that the more cooling energy was supplied to the building. It was concluded that if the EAHE aimed at a high specific energy performance, a small specific surface area should be reached using fewer pipes and if the EAHE aimed at a high temperature ratio, a high specific surface area should be reached using more pipes.

Common configurations of a heat exchanger usually consider one single layer of pipes requiring a large installation area. This major drawback can be overcome using a multiple layer configuration. De Jesus Freire et al. [47] presented a study considering the use of a heat exchanger with a multiple layer configuration, namely, comparing it with a single layer of pipes and describing the major performance differences. A parametric analysis was also performed and it was concluded that the heat exchanger power increases with the layers depth until $3 \mathrm{~m}$ and that the more efficient distance between layers should be kept at $1.5 \mathrm{~m}$. It was found that a one-dimensional discrete model can respond satisfactorily to a performance analysis of compact buried pipes systems, producing results significantly faster than the bidimensional model, within a good accuracy. When the multiple layer configurations are adopted, it was verified that maintaining similar transfer areas and velocity flows incurs a decrease of $3-6 \%$ in the duty delivered by heat exchangers with two and three layers, respectively, when compared to heat exchangers with a single layer. However, this corresponds to a decrease of $50 \%$ and $67 \%$ in the area needed, respectively. This factor is very attractive given the current limitations in urban spaces.

Lee and Strand [30] developed a new module and implemented it in the EnergyPlus program for the simulation of earth tubes. A parametric analysis was carried out using the new module to investigate the effect of each parameter on the overall performance of the earth tube under various conditions during cooling season. Pipe length and pipe depth turned out to affect the overall cooling rate of the earth tube, while pipe radius and air flow rate mainly affect earth tube inlet temperature. It was concluded that if properly designed an earth tube can save more than $50 \%$ of the total cooling load in the cases presented in their paper, depending on the weather and soil conditions. However the earth tube alone cannot replace conventional air-conditioning system in these case studies; it can considerably reduce the cooling load in buildings. The model was validated against the data from other theoretical and experimental studies and showed good agreement with both theoretical and experimental data.

Al-Ajmi et al. [26] developed a theoretical model of an EAHE for predicting the outlet air temperature and cooling potential of these devices in a hot, arid climate. The model was validated against three other studies: Mihalakakou et al. [48], Dhaliwal and Goswami [49], and Shingari [50] and has shown good agreement. A building model representative of a typical Kuwaiti dwelling has been implemented and all the models have been encoded within the TRNSYSIISIBAT environment. It was concluded that the EAHE system alone cannot maintain indoor thermal comfort within the acceptable range $\left(22-27^{\circ} \mathrm{C}\right)$, but it could be used to reduce energy demand in domestic buildings in Kuwait if used in conjunction with an air-conditioning system and have the potential for reducing cooling energy demand in a typical house by $30 \%$ over the peak summer season.

Sethi and Sharma [20] developed a thermal model for heating and cooling of an agricultural greenhouse integrated with an aquifer coupled cavity flow heat exchanger system (ACCFHES). The ACCFHES works on the principal of utilizing deep aquifer water available at the ground surface through an irrigation tube well already installed in every agricultural field at constant year-round temperature of $24^{\circ} \mathrm{C}$. Using the derived analytical expressions, a computer program is developed in $\mathrm{C}++$ for computing the hourly greenhouse plant and room air temperature for various design and climatic parameters. Developed thermal model for the greenhouse integrated to the ACCFHES can be used to predict the plant and room air temperature for any size of greenhouse, time of year, and location. Experimental validation of the developed model was carried out using the measured plant and room air temperature data of the greenhouse (in which Capsicum is grown) for the winter and summer conditions of the year 2004-2005 at Chandigarh $\left(31^{\circ} \mathrm{N}\right.$ and $\left.78^{\circ} \mathrm{E}\right)$, Punjab, India. It was observed that the predicted and measured values were in close agreement. They concluded that, for a greenhouse of $24 \mathrm{~m}^{2}$ area, the ACCFHES with air and water contact area of $12.63 \mathrm{~m}^{2}$ and air mass flow rate of $0.47 \mathrm{~kg} \mathrm{~s}^{-1}$ was sufficient 
to lower the inside room air and plant temperature by 6$7 \mathrm{~K}$ and $5-6 \mathrm{~K}$ below ambient air, respectively, in extreme summer conditions and was also capable of increasing the same by $7-8 \mathrm{~K}$ and $5-6 \mathrm{~K}$ above the ambient air conditions, respectively, in extreme winter conditions. A summary of one-dimensional calculation models is given in Table 1.

\subsection{Two-Dimensional Models of EAHE Systems. The two-} dimensional models of EAHE systems came into practice during the 1990s. Two-dimensional (2D) models allow calculation of ground temperature at surface and at different depths. The finite element programs are used in 2D models to solve two-dimensional conduction problems of EAHE systems. Badescu [51] presented a simple and precise ground heat exchanger model. The thermal behaviour of the heat exchanger was modelled by means of a numerical transient bidimensional approach. The boundary condition at ground surface was derived from an energy balance equation involving the convective energy exchange between air and soil; the solar radiation was absorbed by the ground surface; the latent heat flux due to evaporation at the ground surface as well the long-wave radiation. This approach allows to computing the ground temperature profile at the surface and at various depths. The performance evaluation of the system was done under real climatic conditions. The energy delivered by the ground heat exchanger depends significantly on different design parameters like pipe's depth, diameter, and material.

Zhao et al. [52] presented a study to examine the thermal performance of saturated soil around coaxial ground-coupled heat exchanger (GCHE). The experimental investigation was conducted by means of artificial glass microballs as porous medium. A theoretical model with Darcy's natural convection was developed and numerical solutions were obtained by using Keller's shooting method. There was a better coincidence between experimental and numerical results, which further verified the validation of theoretical model. The results indicated that heat transfer mainly happens near the outer wall of coaxial GCHE and inclines to stabilization at far-field. The inlet temperature, initial temperature of porous medium, and the flow rate were major factors affecting heat transfer. There was a linear relationship between dimensionless temperature gradient along the outer wall of GCHE and the dimensionless height.

Li et al. [27] presented an inner heat source model of underground heat exchanger based on the heat and mass transfer theory in soil. A number of factors such as moisture movement in soil, soil type, and soil property were taken into account in the model. The underground heat exchanger was simplified as the equivalent inner heat source term in the model. The software of Autough2 was used to conduct the numerical simulations. The analyses on the influences of different soil properties and different operation modes on the underground temperature field around the single U-vertical underground heat exchanger were presented in this paper.

Kumar et al. [7] presented the concept of artificial neural network and a computer design tool that can help the designer to evaluate any aspect of earth-to-air heat exchanger and behaviour of the final configuration. The study was mainly focused on those aspects related to the passive heating or cooling performance of the building. They have developed two models for this purpose, namely, deterministic and intelligent. The deterministic model was developed by analyzing simultaneously coupled heat and mass transfer in ground whereas the intelligent model was a development of data driven artificial neural network model. Length, humidity, ambient air temperature, ground surface temperature, ground temperature at burial depth, and air mass flow rate were taken as variables influencing the thermal performance of the earth-to-air heat exchangers. The model was validated against experimental data sets. The intelligent model predicted earth-to-air heat exchanger outlet air temperature with an accuracy of $\pm 2.6 \%$, whereas the deterministic model showed an accuracy of $\pm 5.3 \%$.

Tittelein et al. [53] presented a new numerical model of earth-to-air heat exchangers. The discretised model was solved using response factors method in order to reduce computational time. Each response factor was calculated using a finite elements program that solves $2 \mathrm{D}$ conduction problems. Advantages of the model include the fact that calculation time was reduced by the use of response factors (compared to other similarly accurate methods); it was precise for a short solicitation period (1-day) and a long solicitation period (1-year) as the system was discretised into " $n$ " sections perpendicular to the exchanger pipe that was not the case for the models based on a discretisation of the ground in concentric cylinders and axial meshes and every kind of soil characteristic (inhomogeneous, anisotropic, etc.) and of geometry can be considered due to the response factor calculation in a 2D finite elements program (not as analytical models). A summary of two-dimensional calculation models is given in Table 2 .

2.3. Three-Dimensional Models of EAHE Systems. The threedimensional (3D) models become more popular in recent years because these models are dynamic and technically more advanced which can provide room for all types of grid geometry to produce detailed thermal analysis of EAHE systems. In order to make the performance analysis of EAHE systems using $3 \mathrm{D}$ heat transfer and energy balance equations, the computational fluid dynamic (CFD) played a key role. CFD is a popular and a powerful method to study heat and mass transfer for many years. CFD codes are prepared around the numerical algorithms that can tackle fluid flow problems. The partial differential equations governing airflow and heat transfer can be solved numerically in a discretised form with CFD. The complex fluid flow and heat transfer processes involved in any heat exchanger can be examined by CFD software, FLUENT 6.3. Some of the commercial CFD codes in use are FLUENT, CFX, STAR CD, FIDAP, ADINA, CFD2000, PHOENICS, and others [54].

Bansal et al. [2,3] published papers on performance analysis of earth-pipe-air heat exchanger (EPAHE) systems for winter heating and summer cooling. It was found that EPAHE can be used to reduce the heating load of buildings in winter and can also be used to reduce the cooling load of buildings in summer. A transient and implicit model based on 
TABLE 1: One-dimensional calculation models of EAHE systems.

\begin{tabular}{|c|c|c|c|}
\hline Authors/type & Methodology & $\begin{array}{l}\text { Comparison between } \\
\text { experimental and } \\
\text { simulation results }\end{array}$ & Reference \\
\hline $\begin{array}{l}\text { Santamouris et al. (1995), } \\
\text { earth-to-air heat } \\
\text { exchanger }\end{array}$ & $\begin{array}{l}\text { A mathematical model } \\
\text { based on the principle of } \\
\text { balance point } \\
\text { temperature within the } \\
\text { TRNSYS environment }\end{array}$ & $\begin{array}{l}\text { Sufficient accuracy } \\
\text { observed }\end{array}$ & {$[37]$} \\
\hline $\begin{array}{l}\text { Mihalakakou et al. } \\
\text { (1997), the variation of } \\
\text { the ground surface } \\
\text { temperature for bare and } \\
\text { short-grass covered soil }\end{array}$ & $\begin{array}{l}\text { A mathematical model } \\
\text { based on heat } \\
\text { conduction equations } \\
\text { and on the energy } \\
\text { balance at the ground } \\
\text { surface }\end{array}$ & $\begin{array}{l}\text { Very good agreement } \\
\text { found }\end{array}$ & {$[38]$} \\
\hline $\begin{array}{l}\text { Kabashnikov et al. } \\
\text { (2002), soil heat } \\
\text { exchanger }\end{array}$ & $\begin{array}{l}\text { Mathematical model in } \\
\text { the form of Fourier } \\
\text { integral }\end{array}$ & $\begin{array}{l}\text { Close agreement } \\
\text { observed }\end{array}$ & {$[36]$} \\
\hline $\begin{array}{l}\text { De Paepe and Janssens } \\
\text { (2003), earth-air heat } \\
\text { exchanger }\end{array}$ & $\begin{array}{l}\text { One-dimensional } \\
\text { analytical model }\end{array}$ & $\begin{array}{l}\text { No such comparison } \\
\text { available }\end{array}$ & {$[45]$} \\
\hline $\begin{array}{l}\text { Hollmuller (2003), } \\
\text { cylindrical air/soil heat } \\
\text { exchanger }\end{array}$ & $\begin{array}{l}\text { Analytical solution with } \\
\text { harmonic temperature } \\
\text { signal at input }\end{array}$ & $\begin{array}{l}\text { Good agreement } \\
\text { against a } \\
\text { finite-difference } \\
\text { numerical simulation } \\
\text { model and against an } \\
\text { experimental setup }\end{array}$ & {$[28]$} \\
\hline $\begin{array}{l}\text { Pfafferott (2003), } \\
\text { earth-to-air heat } \\
\text { exchanger }\end{array}$ & $\begin{array}{l}\text { Thermal efficiency } \\
\text { characterization of } \\
\text { EAHE by using } \\
\text { parametric model and } \\
\text { standardized graphs }\end{array}$ & $\begin{array}{l}\text { No such comparison } \\
\text { available }\end{array}$ & {$[17]$} \\
\hline $\begin{array}{l}\text { Ghosal et al. (2005), } \\
\text { ground air collector and } \\
\text { earth-air heat exchanger, } \\
\text { integrated with the } \\
\text { greenhouse }\end{array}$ & $\begin{array}{l}\text { A complete numerical } \\
\text { model was developed }\end{array}$ & $\begin{array}{l}\text { Fair agreement } \\
\text { observed }\end{array}$ & {$[25]$} \\
\hline $\begin{array}{l}\text { Al-Ajmi et al. (2006), } \\
\text { earth-air heat exchanger }\end{array}$ & $\begin{array}{l}\text { Theoretical model } \\
\text { within the } \\
\text { TRNSYS-IISIBAT } \\
\text { environment }\end{array}$ & $\begin{array}{l}\text { Good agreement } \\
\text { showed }\end{array}$ & {$[26]$} \\
\hline $\begin{array}{l}\text { Sethi and Sharma } \\
\text { (2007), aquifer coupled } \\
\text { cavity flow heat } \\
\text { exchanger system } \\
\text { (ACCFHES) }\end{array}$ & $\begin{array}{l}\text { Thermal model for } \\
\text { heating and cooling of } \\
\text { greenhouse solved } \\
\text { within } \mathrm{C}^{++} \\
\text {programming }\end{array}$ & $\begin{array}{l}\text { Close agreement } \\
\text { observed }\end{array}$ & {$[20]$} \\
\hline $\begin{array}{l}\text { Lee and Strand (2008), } \\
\text { earth tubes }\end{array}$ & $\begin{array}{l}\text { A new module was } \\
\text { developed for and } \\
\text { implemented in the } \\
\text { EnergyPlus program }\end{array}$ & $\begin{array}{l}\text { Good agreement with } \\
\text { both theoretical and } \\
\text { experimental data } \\
\text { showed }\end{array}$ & [30] \\
\hline $\begin{array}{l}\text { Cucumo et al. (2008), } \\
\text { earth-to-air heat } \\
\text { exchanger }\end{array}$ & $\begin{array}{l}\text { One-dimensional } \\
\text { transient analytical } \\
\text { model }\end{array}$ & $\begin{array}{l}\text { A very satisfactory } \\
\text { agreement observed }\end{array}$ & {$[46]$} \\
\hline $\begin{array}{l}\text { Ben Jmaa Derbel and } \\
\text { Kanoun (2010), earth } \\
\text { fluid pipe system }\end{array}$ & $\begin{array}{l}\text { A mathematical model } \\
\text { validated by measured } \\
\text { ground temperatures }\end{array}$ & $\begin{array}{l}\text { Good agreement } \\
\text { showed }\end{array}$ & [39] \\
\hline $\begin{array}{l}\text { Sehli et al. (2012), } \\
\text { earth-air heat exchanger }\end{array}$ & $\begin{array}{l}\text { One-dimensional steady } \\
\text { numerical model }\end{array}$ & $\begin{array}{l}\text { Satisfactory } \\
\text { agreement observed }\end{array}$ & {$[43]$} \\
\hline
\end{tabular}


TABle 1: Continued.

\begin{tabular}{lll}
\hline Authors/type & Methodology & $\begin{array}{l}\text { Comparison between } \\
\text { experimental and } \\
\text { simulation results }\end{array}$ \\
\hline $\begin{array}{l}\text { Su et al. (2012), air-earth- } \\
\text { (rock-) tunnel system }\end{array}$ & $\begin{array}{l}\text { 1D numerical simulating } \\
\text { model }\end{array}$ & $\begin{array}{l}\text { Max. error: } \\
\text { temperature }=1.4^{\circ} \mathrm{C} ; \\
\text { R. humidity }=10 \%\end{array}$ \\
\hline $\begin{array}{l}\text { De Jesus Freire et al. } \\
\text { (2013), compact buried } \\
\text { pipes system }\end{array}$ & $\begin{array}{l}\text { One-dimensional } \\
\text { discrete model simulated } \\
\text { within TRNSYS } \\
\text { environment }\end{array}$ & $\begin{array}{l}\text { Good accuracy } \\
\text { observed }\end{array}$ \\
\hline $\begin{array}{l}\text { Ozgener et al. (2013), } \\
\text { geothermal (ground) } \\
\text { heat exchangers }\end{array}$ & $\begin{array}{l}\text { One-dimensional } \\
\text { transient heat flow } \\
\text { model }\end{array}$ & $\begin{array}{l}\text { Good accuracy } \\
\text { observed }\end{array}$ \\
\hline
\end{tabular}

TABLE 2: Two-dimensional calculation models of EAHE systems.

\begin{tabular}{|c|c|c|c|}
\hline Authors/type & Methodology & $\begin{array}{l}\text { Comparison between } \\
\text { experimental and } \\
\text { simulation results }\end{array}$ & Reference \\
\hline $\begin{array}{l}\text { Li et al. (2005), } \\
\text { underground heat } \\
\text { exchanger (UHE) }\end{array}$ & $\begin{array}{l}\text { Inner heat source model } \\
\text { of (UHE) solved by } \\
\text { Autough2 software }\end{array}$ & $\begin{array}{l}\text { No such comparison } \\
\text { available }\end{array}$ & [27] \\
\hline $\begin{array}{l}\text { Kumar et al. (2006), } \\
\text { earth-to-air heat } \\
\text { exchanger }\end{array}$ & $\begin{array}{l}\text { Artificial neural network } \\
\text { (ANN) using } \\
\text { deterministic and } \\
\text { intelligent models }\end{array}$ & Good agreement showed & {$[7]$} \\
\hline $\begin{array}{l}\text { Badescu (2007), ground } \\
\text { heat exchanger }\end{array}$ & $\begin{array}{l}\text { A numerical transient } \\
\text { bidimensional model }\end{array}$ & $\begin{array}{l}\text { No such comparison } \\
\text { available }\end{array}$ & {$[51]$} \\
\hline $\begin{array}{l}\text { Zhao et al. (2008), } \\
\text { ground-coupled heat } \\
\text { exchanger } \\
\text { (GCHE) }\end{array}$ & $\begin{array}{l}\text { A theoretical model } \\
\text { solved by Keller } \\
\text { shooting method }\end{array}$ & Good agreement showed & {$[52]$} \\
\hline $\begin{array}{l}\text { Tittelein et al. (2009), } \\
\text { earth-to-air heat } \\
\text { exchanger }\end{array}$ & $\begin{array}{l}\text { Finite elements program } \\
\text { that solves } 2 \mathrm{D} \\
\text { conduction problems }\end{array}$ & $\begin{array}{l}\text { No such comparison } \\
\text { available }\end{array}$ & {$[53]$} \\
\hline
\end{tabular}

CFD was developed to forecast the thermal performance and heating/cooling capacity of EPAHE systems. The FLUENT simulation program was used to develop the model. The model developed was validated against experimental investigations on an experimental setup in Ajmer, western India. Effects of the operating parameters (i.e., the pipe material and air velocity) on the thermal performance of earth-air-pipe heat exchanger systems were studied. For the pipe of $23.42 \mathrm{~m}$ in length and $0.15 \mathrm{~m}$ diameter, temperature rise of $4.1-4.8^{\circ} \mathrm{C}$ has been observed in winter and cooling in the range of 8.0$12.7^{\circ} \mathrm{C}$ has been observed in summer for the flow velocity ranging from 2 to $5 \mathrm{~m} / \mathrm{s}$. Investigations on steel and PVC pipes have shown that performance of the EPAHE system is not significantly affected by the material of the buried pipe.

Bansal et al. [55] revealed that the performance of simple earth-air-tunnel heat exchanger (EATHE) was enhanced by integrating an evaporative cooler at the outlet. The multiphase CFD modelling with FLUENT software (version 6.3) was used for carrying out year-round hourly analysis of the integrated system for hot and dry climatic conditions of
Ajmer, India. It was observed that during summer season a simple EATHE system provides $4500 \mathrm{MJ}$ of cooling effect, while $3109 \mathrm{MJ}$ of additional cooling effect can be achieved by integrating evaporative cooler with the EATHE. Analyses of the $8760 \mathrm{~h}$ showed that the EATHE system was capable of providing $4856 \mathrm{MJ}$ equivalent of heating effect at such locations. Results showed considerable improvement in effectiveness of the EATHE system when integrated with evaporative cooler in hot and dry climatic conditions.

Bansal et al. [56] developed a transient and implicit model based on computational fluid dynamics for evaluating the energy saving obtained by the use of EATHE system integrated with evaporative cooling system. The amount of electrical energy saved (kWh/year) for producing the cooling/heating effect by the proposed EATHE system has been calculated with different types of blowers. It was found that, with an energy efficient blower, the financial payback period of integrated EATHE-evaporative cooling system is about 2 years while the systems with inefficient blower are financially not viable due to much higher payback. It was noted that the 
amount of electrical energy saved is significantly dependent on the electric tariff and the energy efficiency of the blower used in the proposed EATHE system.

Bansal et al. [57] presented a new concept of "derating factor" for assessing decline in thermal performance of EATHE under transient operating conditions in predominantly hot and dry climate of Ajmer, India, using experimental and CFD modelling with FLUENT software. The "derating factor" was defined as the ratio of the difference between the drop in air temperature obtained by EATHE in steady state and in transient state and the drop in air temperature obtained by EATHE in steady state. The derating factor was found to be a function of thermal conductivity of soil, duration of continuous operation of EATHE, and length of pipe. It was concluded that higher thermal conductivity of the soil situated in the immediate vicinity of the EATHE pipe results in better thermal performance of EATHE and, during optimization of the thermal performance of EATHE, derating factor should be considered to ensure that the EATHE would be able to give a consistent thermal performance for longer period of operation. The greater decline in thermal performance of EATHE was observed for higher values of "derating factor." It was found for different cases analyzed that the range of derating varies from minimum $0.2 \%$ to maximum as $68 \%$, which if ignored while designing may lead to poor performance of EATHEs.

Misra et al. [58] evaluated thermal performance of EATHE under transient operating conditions for predominantly hot and dry climate of Ajmer, India, using experimental and CFD modeling. The following fundamental equations of fluid flow and heat transfer have been used in the analysis.

Continuity equation:

$$
\frac{\partial u}{\partial x}+\frac{\partial v}{\partial y}+\frac{\partial w}{\partial z}=0
$$

$x$-Momentum equation:

$$
\begin{aligned}
& {\left[u \frac{\partial u}{\partial x}+v \frac{\partial u}{\partial y}+w \frac{\partial u}{\partial z}\right]} \\
& =-\frac{1}{\rho} \frac{\partial P}{\partial x}+\vartheta\left[\frac{\partial^{2} u}{\partial x^{2}}+\frac{\partial^{2} u}{\partial y^{2}}+\frac{\partial^{2} u}{\partial z^{2}}\right]
\end{aligned}
$$

$y$-Momentum equation:

$$
\begin{aligned}
& {\left[u \frac{\partial v}{\partial x}+v \frac{\partial v}{\partial y}+w \frac{\partial v}{\partial z}\right]} \\
& =-\frac{1}{\rho} \frac{\partial P}{\partial y}+\vartheta\left[\frac{\partial^{2} v}{\partial x^{2}}+\frac{\partial^{2} v}{\partial y^{2}}+\frac{\partial^{2} v}{\partial z^{2}}\right]
\end{aligned}
$$

$z$-Momentum equation:

$$
\begin{aligned}
& {\left[u \frac{\partial w}{\partial x}+v \frac{\partial w}{\partial y}+w \frac{\partial w}{\partial z}\right]} \\
& =-\frac{1}{\rho} \frac{\partial P}{\partial z}+\vartheta\left[\frac{\partial^{2} w}{\partial x^{2}}+\frac{\partial^{2} w}{\partial y^{2}}+\frac{\partial^{2} w}{\partial z^{2}}\right]
\end{aligned}
$$

Energy equation:

$$
\left[u \frac{\partial T}{\partial x}+v \frac{\partial T}{\partial y}+w \frac{\partial T}{\partial z}\right]=\alpha\left[\frac{\partial^{2} T}{\partial x^{2}}+\frac{\partial^{2} T}{\partial y^{2}}+\frac{\partial^{2} T}{\partial z^{2}}\right] .
$$

In the above equations (1)-(5), $u, v$, and $w$ are the velocity components in $x, y$, and $z$ directions, $p$ and $T$ are the pressure and temperature of the flowing air, $\vartheta \mathcal{~ i s ~ k i n e m a t i c ~ v i s c o s i t y , ~}$ and $\alpha$ is soil thermal diffusivity.

It was found that the transient thermal performance of EATHE was significantly dependent on thermal conductivity of the soil and duration of its continuous operation. The effect of pipe diameter on thermal performance of EATHE system due to its prolonged use was the least in case of soil with higher value of thermal conductivity and an increase in flow velocity leads to drop in thermal performance. Under steady-state condition, drop of $18.8^{\circ} \mathrm{C}$ in air temperature was obtained, whereas under transient conditions cooling of air reduced from $18.7^{\circ} \mathrm{C}$ to $16.6^{\circ} \mathrm{C}$ for soil thermal conductivity of $0.52 \mathrm{Wm}^{-1} \mathrm{~K}^{-1}$, after $24 \mathrm{~h}$ of continuous operation.

Bansal et al. [59] accomplished thermal performance investigation for different pipe length of EATHE taking into account the effect of soil thermal conductivity and time period of continuous operation of EATHE. The main purpose of the CFD study was to investigate the transient behaviour of simple EATHE system used in continuous cooling mode. The experimental setup has been developed and validated for summer weather conditions for the month of June, 2011, Ajmer, western India. A small difference (3.4$8.0 \%$ ) between the experimental and simulated values was observed and hence the CFD model was valid. Maximum air temperature drops of $15.6,17.0$, and $17.3 \mathrm{~K}$ were observed for soil thermal conductivities of $0.52,2$, and $4 \mathrm{Wm}^{-1} \mathrm{~K}^{-1}$, respectively. Maximum deterioration in the performance in terms of temperature drop obtained during continuous operation of $24 \mathrm{~h}$ was recorded as $2.9 \mathrm{~K}$ for soil with thermal conductivity of $0.52 \mathrm{Wm}^{-1} \mathrm{~K}^{-1}$. Thickness of soil annulus surrounding the pipe up to which the thermal influence was observed depended on the thermal conductivity of the soil and period of continuous running of EATHE system. The thickness of the soil annulus beyond which no significant rise in temperature of soil was observed was equal to the pipe diameter. It was concluded that soil properties play a key role in design of EATHE system and the initial length of EATHE pipe majorly contributes to thermal performance of EATHE system and this contribution was larger for soil with higher thermal conductivity.

Genetic algorithms (GAs) have emerged as powerful optimization tool for analyzing the problem like earthto-air heat exchanger (EAHE) and consequently thermal 
performance of non-air-conditioned building. Kumar et al. [60] proposed a new optimization method based on GA to generate optimized EAHE design parameters. To determine heating and cooling potential of an EAHE, deterministic and intelligent models were employed. The GA designed model comprises greater accuracy than the earlier models. The proposed model explained natural thermal stratification of the ground, humidity variations of circulating air, ground surface conditions, latent and sensible heat transfer, and so forth. The results showed very good agreement with the experimental data and other model predictions.

Gustafsson et al. [61] studied ground water filled borehole heat exchanger (BHE) having common U-pipe arrangement by a three-dimensional, steady-state CFD model. The numerical model showed good agreement with theoretical studies and experimental work. Wu et al. [29] developed a transient and implicit numerical model based on coupled simultaneous heat transfer and turbulent flow to predict the thermal performance and evaluate the cooling capacity of earth-airpipe systems. The model incorporated the effect of turbulent air flow on the thermal performance. It was observed that the model predictions agree well with the experimental results. The model was developed in CFD (PHOENICS platform). AlKhoury et al. [62] presented a finite element modeling technique for double U-tube borehole heat exchangers (BHE) and the surrounding soil mass. The numerical analysis of a $\mathrm{BHE}$ model was done to simulate three-dimensional heat transfer processes in multiple borehole heat exchangers embedded in a multilayer soil mass. A validation of computed results with measured results was presented. Utilizing the model for research works and designing optimization parametric analyses were also presented. Vaz et al. [63] conducted experimental and numerical analysis of an EAHE which was used to reduce high grade energy consumption for space conditioning of buildings by utilizing thermal potential of soil. The numerical solution of the conservation equations of the problem was performed with a commercial code (FLUENT) which was based on the finite volume method (FVM). Turbulence was tackled with the Reynolds stress model (RSM). They did comparative study between the numerical and experimental results of air temperature inside the ducts. A maximum difference of less than $15 \%$ was found, validating the numerical model proposed.

Mnasri et al. [64] presented the study of transient flow under forced convection in buried coaxial exchanger. The wall temperature and the wall heat flux and the heat transfer coefficient were unknown. A hybrid model consisting of a finite element method at the boundary (BEM) for the heat transfer problem on the boundary and a finite volume method (FVM) to solve the laminar flow inside solved this problem. The development of the BEM method was based on Green's function theory. This conjugate method allowed one to have fast results and to foresee the thermal behavior of the exchanger. The heat transfer coefficients were investigated. The results were compared to those obtained using the commercial CFD package Fluent.

Khalajzadeh et al. [65] performed thermal performance analysis of a novel hybrid system of ground heat exchanger (GHE) and indirect evaporative cooler (IEC) in summer conditions of Tehran, Iran. In order to have an accurate prediction of the optimum performance of the groundcoupled circuit, a three-dimensional computational fluid dynamics simulation was run. The simulation results showed that the hybrid system of GHE and ICE can easily provide comfort conditions and gave cooling effectiveness more than unity. The proposed hybrid system was able to do space conditioning in summer conditions of Tehran, Iran.

Flaga-Maryanczyka et al. [66] presented the experimental measurements and numerical simulation of a ground source heat exchanger operating at a cold climate for a passive house ventilation system. The investigated passive house is located in the south of Poland. The calculations were made with the CFD ANSYS FLUENT software package. The CFD simulations performed for the ground source heat exchanger operating for the passive house ventilation system for February, based on experimental data, showed good correlation with the measured values. The calculated RMS error is $0.62 \%$ which means that the difference between calculated and measured values is 1.7 degree on average. Finally, it was concluded that CFD tool is suitable for simulations of the ground source heat exchanger operating at the cold climate for the passive house ventilation system.

Ramírez-Dávila et al. [67] conducted a numerical study for predicting the thermal behaviour of an earth-to-air heat exchanger (EAHE) for three cities in México. A computational fluid dynamics code based on the finite volume method has been developed in order to model the EAHE. Simulations have been conducted for sand, silt, and clay soil textures for the cities of Ciudad Juárez, México City, and Mérida, respectively, and, also, for different Reynolds numbers, $\mathrm{Re}=$ $100,500,1000$, and 1500 through one year. It was disclosed in simulation results that the thermal performance of the EAHE is better in summer than in winter, decreasing the air temperature in an average of 6.6 and $3.2^{\circ} \mathrm{C}$ for summer and increasing it in 2.1 and $2.7^{\circ} \mathrm{C}$ for winter, for Ciudad Juárez and México City, respectively. On the contrary, EAHE had its best thermal performance in winter, increasing the air temperature in $3.8^{\circ} \mathrm{C}$ for Mérida. It was concluded that the use of EAHEs is suitable for heating or cooling of buildings in lands of extreme and moderate temperatures where the thermal inertia effect in soil is higher.

Mihalakakou et al. [68] presented a transient, numerical model for the prediction of the ground temperature at various depths below buildings. The proposed model was developed by calculating the heat flow to the ground from a building, which depends on the complicated three-dimensional thermal process in the ground. The main difficulties in obtaining manageable solutions of the heat flow problem were the three-dimensionality of the thermal process, the strong temporal variability of the outdoor temperature, and the large number of parameters involved in describing the building foundation geometry as well as the thermal insulation. The techniques of superposition and numerical analysis were used to cope with these difficulties. The model was validated against experimental data and it was found that it could accurately predict the ground temperature under a building.

Mihalakakou [69] presented a paper on the heating potential of a single buried pipe using real climatic data. The 
system's heating potential was calculated using an accurate, dynamic, deterministic, numerical model. Multiyear ambient air and soil climatic data for the city of Athens have been used as inputs to the deterministic model and the results were compared. A neural network approach was also used for estimating the thermal performance of the system in heating. The influence of several climatic parameters used as inputs to the neural model such as the ambient air temperature, the ground temperature, and the relative humidity is investigated and analysed. Gauthier et al. [34] developed a numerical model for the prediction of the thermal behaviour of a soil heat exchanger-storage system (SHESS) designed for reducing the energy consumption of greenhouses. The transient fully 3D heat transfer model was based on the energy conservation equations for the soil and the circulating air. The condensation and evaporation rates inside the pipes were calculated by considering the nonhomogeneous properties of the soil. The model was validated with experimental data taken from a SHESS installed in a commercial type greenhouse. It was concluded that burying pipes in deeper underground allows more energy to be stored during the day but less is recovered at night through the ground surface and the overall performance declines.

Breesch et al. [70] applied natural night ventilation and an earth-to-air heat exchanger in the low-energy office building SD Worx, Kortrijk, Belgium. It was concluded that these passive cooling techniques perform well and create a good thermal summer comfort and save conventional energy consumption for creating comfort conditions. Simulations with the coupled thermal and ventilation simulation model TRNSYS-COMIS demonstrated that natural night ventilation was more efficient to improve thermal summer comfort than an earth-to-air heat exchanger.

Badescu and Isvoranu [71] proposed an analytical pneumatic and thermal design procedure for earth-to-air heat exchangers (EAHEs) of registry type. The procedure allows choosing between different EAHE geometrical configurations and between the two usual air circulation paths inside the EAHE (i.e., the Z- and П-paths, resp.). The implementation of the design procedure is made for the EAHE of a large passive house $(\mathrm{PH})$ built near Bucharest, Romania (AMVIC $\mathrm{PH}$ ). A time-dependent simulation of EAHE's operation was performed. It allowed computing the soil temperature profile at the surface and at various depths and the air temperature distribution inside the EAHE. The simulation results were validated against experimental results. The annual heating/cooling potential of EAHE was investigated. It was found that the energy delivered by the EAHE depends significantly on the geometrical configuration. For further checking the results predicted by the design procedure a computational fluid dynamics (CFD) analysis was performed. A good agreement was observed between the outputs predicted by the CFD model and existing measurements. From a thermal point of view the Z-path EAHE is always preferable to the $\Pi$ path device.

A summary of three-dimensional calculation models is given in Table 3.

\section{Conclusions}

The earth-air heat exchangers are promising and effective technology for space conditioning of buildings. It is a device which utilizes heat capacity of earth effectively. The EAHE system, if properly designed, can be feasible and economical option to replace conventional air-conditioning systems as there is no need of compressors, burners, or chemicals and only blowers are required to move the air. A well-designed EAHE can reduce electricity consumption of a typical house by $30 \%$. Therefore modeling, simulation, and testing of EAHE systems are very essential for getting optimum output. EAHEs usually supply more heating and cooling energy than the primary energy they use for power input for the fan or pump.

Modeling is very useful tool in order to predict the effect of the operating parameters like pipe length, radius, depth of burial, and air flow rate on the thermal performance and heating/cooling capacity of EAHE systems. In the literature several calculation models are found to simulate the thermophysical behavior of earth-air heat exchangers. Different parametric and numerical models for EAHEs have been published in the last two decades. Simulation models can be classified as models with an analytical or a numerical solution of the ground temperature field and mixed models. The analysis of EAHE systems started with the development of one-dimensional models. The two-dimensional models came into practice during the 1990s and were replaced by three-dimensional models in recent years.

Three-dimensional models are dynamic and technically more advanced which can provide room for all types of grid geometry to produce detailed thermal analysis of EAHE systems but their applicability for design is limited to the people who are able to use the calculation codes. In $3 \mathrm{D}$ models finite volume method was used to solve 3D conduction equations. Two-dimensional (2D) models allow calculation of ground temperature at surface and at different depths. The finite element programs are used in 2D models to solve two-dimensional conduction problems of EAHE systems. In one-dimensional model the description of the pipe to derive a relation between its inlet and outlet temperature is used and therefore it is very simple to solve and get the design parameters. It can be concluded that $1 \mathrm{D}$ models are simplest to solve within shortest time period but are not able to analyze the EAHE system completely. In comparison to $1 \mathrm{D}$ models, 2D and 3D models are time consuming but are able to produce more accurate results. Presently, 3D models are more popular among researchers as they are able to handle any complex problem and provide complete thermal analysis of the EAHE system.

The performance of EAHE system can further be improved by integrating it with nonconventional energy sources like solar, wind energy, and so forth. It may be concluded that proficient use of EAHE systems in amalgamation with renewable energy sources and newest technology will play vital role in saving high grade energy consumption and environment at global level. In this view, it is expected by authors that this review paper will be very useful to 
TABLE 3: Three-dimensional calculation models of EAHE systems.

\begin{tabular}{|c|c|c|c|}
\hline Authors/type & Methodology & $\begin{array}{l}\text { Comparison between } \\
\text { experimental and } \\
\text { simulation results }\end{array}$ & Reference \\
\hline $\begin{array}{l}\text { Mihalakakou et al. } \\
\text { (1995), ground } \\
\text { temperature prediction } \\
\text { at various depths }\end{array}$ & $\begin{array}{l}\text { A transient numerical } \\
\text { model }\end{array}$ & $\begin{array}{l}\text { An accurate agreement } \\
\text { observed }\end{array}$ & {$[68]$} \\
\hline $\begin{array}{l}\text { Gauthier et al. (1997), } \\
\text { soil heat } \\
\text { exchanger-storage } \\
\text { system (SHESS) }\end{array}$ & $\begin{array}{l}\text { A transient numerical } \\
\text { model simulated in } \\
\text { software FLOW3D } \\
(\text { AEA, 1992) }\end{array}$ & $\begin{array}{l}\text { A remarkable agreement } \\
\text { observed }\end{array}$ & {$[34]$} \\
\hline $\begin{array}{l}\text { Mihalakakou (2003), } \\
\text { buried pipe }\end{array}$ & $\begin{array}{l}\text { (i) An accurate, } \\
\text { dynamic, deterministic, } \\
\text { numerical model } \\
\text { (TRNSYS) } \\
\text { (ii) A neural network } \\
\text { approach }\end{array}$ & $\begin{array}{l}\text { Good agreement } \\
\text { observed }\end{array}$ & [69] \\
\hline $\begin{array}{l}\text { Breesch et al. (2005), } \\
\text { earth-to-air heat } \\
\text { exchanger }\end{array}$ & $\begin{array}{l}\text { Simulation model } \\
\text { TRNSYS-COMIS }\end{array}$ & $\begin{array}{l}\text { No such comparison } \\
\text { available }\end{array}$ & {$[70]$} \\
\hline $\begin{array}{l}\text { Wu et al. (2007), } \\
\text { earth-air-pipe systems }\end{array}$ & $\begin{array}{l}\text { CFD platform, } \\
\text { PHOENICS }\end{array}$ & $\begin{array}{l}\text { Good agreement } \\
\text { obtained }\end{array}$ & {$[29]$} \\
\hline $\begin{array}{l}\text { Kumar et al. (2008), } \\
\text { earth-to-air heat } \\
\text { exchanger }\end{array}$ & $\begin{array}{l}\text { The fully implicit, } \\
\text { transient model solved } \\
\text { in MATLAB (version } \\
6.5 \text { ) and validated with } \\
\text { numerical solutions } \\
\text { from FLUENT }\end{array}$ & $\begin{array}{l}\text { Very good agreement } \\
\text { showed }\end{array}$ & {$[60]$} \\
\hline $\begin{array}{l}\text { Bansal et al. (2009), } \\
\text { earth-pipe-air heat } \\
\text { exchanger (EPAHE) }\end{array}$ & $\begin{array}{l}\text { A transient and implicit } \\
\text { model. CFD code: } \\
\text { FLUENT } 6.3 \text { (standard } \\
\text { k-e model) }\end{array}$ & Fair agreement observed & {$[2]$} \\
\hline $\begin{array}{l}\text { Gustafsson et al. (2010), } \\
\text { borehole heat } \\
\text { exchangers (BHE) }\end{array}$ & $\begin{array}{l}\text { Steady-state CFD model: } \\
\text { FLUENT }\end{array}$ & $\begin{array}{l}\text { Good agreement } \\
\text { observed }\end{array}$ & {$[61]$} \\
\hline $\begin{array}{l}\text { Al-Khoury et al. (2010), } \\
\text { borehole heat } \\
\text { exchangers (BHE) }\end{array}$ & $\begin{array}{l}\text { A finite element } \\
\text { modeling (FEM) } \\
\text { technique used }\end{array}$ & $\begin{array}{l}\text { Good agreement } \\
\text { observed }\end{array}$ & {$[62]$} \\
\hline $\begin{array}{l}\text { Mnasri et al. (2010), } \\
\text { buried coaxial } \\
\text { exchanger }\end{array}$ & $\begin{array}{l}\text { A hybrid model of finite } \\
\text { volume method (FVM) } \\
\text { and the boundary } \\
\text { element method (BEM) } \\
\text { is used }\end{array}$ & $\begin{array}{l}\text { No such comparison } \\
\text { available }\end{array}$ & {$[64]$} \\
\hline $\begin{array}{l}\text { Bansal et al. (2010), } \\
\text { earth-pipe-air heat } \\
\text { exchanger (EPAHE) }\end{array}$ & $\begin{array}{l}\text { A transient and implicit } \\
\text { model. CFD code: } \\
\text { FLUENT } 6.3 \text { (standard } \\
\text { k-e model) }\end{array}$ & $\begin{array}{l}\text { Good agreement } \\
\text { observed }\end{array}$ & {$[3]$} \\
\hline $\begin{array}{l}\text { Vaz et al. (2011), } \\
\text { earth-air heat } \\
\text { exchanger }\end{array}$ & $\begin{array}{l}\text { (i) Finite volume method } \\
\text { (FVM) code: FLUENT } \\
\text { (ii) Turbulence is tackled } \\
\text { with the Reynolds stress } \\
\text { model (RSM) }\end{array}$ & $\begin{array}{l}\text { The highest difference } \\
\text { found was lower than } \\
15 \%\end{array}$ & {$[63]$} \\
\hline $\begin{array}{l}\text { Badescu and Isvoranu } \\
\text { (2011), earth-to-air heat } \\
\text { exchangers (EAHEs) of } \\
\text { registry type }\end{array}$ & $\begin{array}{l}\text { Computational fluid } \\
\text { dynamics (CFD) model }\end{array}$ & $\begin{array}{l}\text { A good agreement } \\
\text { observed }\end{array}$ & {$[71]$} \\
\hline
\end{tabular}


TABLE 3: Continued.

\begin{tabular}{|c|c|c|c|}
\hline Authors/type & Methodology & $\begin{array}{l}\text { Comparison between } \\
\text { experimental and } \\
\text { simulation results }\end{array}$ & Reference \\
\hline $\begin{array}{l}\text { Bansal et al. (2012), } \\
\text { earth-air-tunnel heat } \\
\text { exchanger (EATHE) }\end{array}$ & $\begin{array}{l}\text { Multiphase CFD } \\
\text { modeling: FLUENT } 6.3\end{array}$ & $\begin{array}{l}\text { Difference of DBT }= \\
3.4-8.0 \% ; \mathrm{RH}= \\
2.5-6.4 \%\end{array}$ & {$[55]$} \\
\hline $\begin{array}{l}\text { Bansal et al. (2012), } \\
\text { EATHE system } \\
\text { integrated with } \\
\text { evaporative cooling } \\
\text { system }\end{array}$ & $\begin{array}{l}\text { Transient and implicit } \\
\text { model based on } \\
\text { computational fluid } \\
\text { dynamics }\end{array}$ & $\begin{array}{l}\text { No such comparison } \\
\text { available }\end{array}$ & {$[56]$} \\
\hline $\begin{array}{l}\text { Khalajzadeh et al. (2012), } \\
\text { ground heat exchanger } \\
\text { (GHE) and indirect } \\
\text { evaporative cooler (IEC) } \\
\text { hybrid system }\end{array}$ & $\begin{array}{l}\text { Mathematical model } \\
\text { simulated in } 3 \mathrm{D} \text { CFD } \\
\text { software }\end{array}$ & $\begin{array}{l}\text { No such comparison } \\
\text { available }\end{array}$ & {$[65]$} \\
\hline $\begin{array}{l}\text { Misra et al. (2013), } \\
\text { earth-air-tunnel heat } \\
\text { exchanger (EATHE) }\end{array}$ & CFD code: FLUENT 6.3 & $\begin{array}{l}\text { The range of derating } \\
\text { min. } 0 \% \text { to max. } 64 \%\end{array}$ & {$[58]$} \\
\hline $\begin{array}{l}\text { Bansal et al. (2013), } \\
\text { earth-air-tunnel heat } \\
\text { exchanger (EATHE) }\end{array}$ & $\begin{array}{l}\text { CFD code: GAMBIT } \\
\text { version } 2.3\end{array}$ & $\begin{array}{l}\text { Small difference } \\
(3.4-8.0 \%) \text { is observed }\end{array}$ & {$[57]$} \\
\hline $\begin{array}{l}\text { Flaga-Maryanczyka et al. } \\
\text { (2014), ground source } \\
\text { heat exchanger }\end{array}$ & $\begin{array}{l}\text { CFD ANSYS FLUENT } \\
\text { software package }\end{array}$ & $\begin{array}{l}\text { Good agreement } \\
\text { observed }\end{array}$ & {$[66]$} \\
\hline $\begin{array}{l}\text { Ramírez-Dávila et al. } \\
\text { (2014), earth-to-air heat } \\
\text { exchanger (EAHE) }\end{array}$ & $\begin{array}{l}\text { A computational fluid } \\
\text { dynamics code based on } \\
\text { the finite volume } \\
\text { method }\end{array}$ & $\begin{array}{l}\text { No such comparison } \\
\text { available }\end{array}$ & {$[67]$} \\
\hline
\end{tabular}

researchers and scientists working in the field of modeling of EAHE systems used for passive heating/cooling of buildings.

\section{Abbreviations}

EAT: $\quad$ Earth-air-tunnel

SHESS: Soil heat exchanger-storage system

FVM: $\quad$ Finite volume method

ACCFHES: Aquifer coupled cavity flow heat exchanger system

IEC: Indirect evaporative cooler

GCHE: Ground-coupled heat exchanger

BEM: $\quad$ Boundary element method

BHE: $\quad$ Borehole heat exchanger

EAHE: Earth-air heat exchanger

CFCs: Chlorofluorocarbons

UAT: Underground air tunnels

CFD: $\quad$ Computational fluid dynamics

ANN: Artificial neural network

GA: Genetic algorithm.

\section{Conflict of Interests}

The authors declare that there is no conflict of interests regarding the publication of this paper.

\section{References}

[1] T. S. Bisoniya, A. Kumar, and P. Baredar, "Experimental and analytical studies of earth-air heat exchanger (EAHE) systems in India: a review," Renewable and Sustainable Energy Reviews, vol. 19, pp. 238-246, 2013.

[2] V. Bansal, R. Misra, G. D. Agrawal, and J. Mathur, "Performance analysis of earth-pipe-air heat exchanger for winter heating," Energy and Buildings, vol. 41, no. 11, pp. 1151-1154, 2009.

[3] V. Bansal, R. Misra, G. D. Agrawal, and J. Mathur, "Performance analysis of earth-pipe-air heat exchanger for summer cooling," Energy and Buildings, vol. 42, no. 5, pp. 645-648, 2010.

[4] N. K. Bansal, M. S. Sodha, and S. S. Bharadwaj, "Performance of Earth-air tunnel system," International Journal of Energy Research, vol. 7, no. 4, pp. 333-345, 1983.

[5] S. S. Bharadwaj and N. K. Bansal, "Temperature distribution inside ground for various surface conditions," Building and Environment, vol. 16, no. 3, pp. 183-192, 1981.

[6] M. Santamouris, A. Argiriou, and M. Vallindras, "Design and operation of a low energy consumption passive solar agricultural greenhouse," Solar energy, vol. 52, no. 5, pp. 371-378, 1994.

[7] R. Kumar, S. C. Kaushik, and S. N. Garg, "Heating and cooling potential of an earth-to-air heat exchanger using artificial neural network," Renewable Energy, vol. 31, no. 8, pp. 1139-1155, 2006. 
[8] S. Milun, T. Kilić, and O. Bego, "Measurement of soil thermal properties by spherical probe," IEEE Transactions on Instrumentation and Measurement, vol. 54, no. 3, pp. 1219-1226, 2005.

[9] M. S. Kersten, "Laboratory research for the determination of the thermal properties of soils," Bulletin No. 28, Engineering Experiment Station, University of Minnesota, Minneapolis, Minn, USA, 1949.

[10] D. A. de Vries, “Thermal properties of soils," in Physics of Plant Environment, W. R. van Wijk, Ed., North-Holland, Amsterdam, The Netherlands, 1963.

[11] D. A. de Vries, "Heat transfer in soils," in Heat and Mass Transfer in the Biosphere, D. A. de Vries and N. H. Afgan, Eds., pp. 5-28, Scripta Book, Washington, Wash, USA, 1975.

[12] D. Hillel, Introduction to Soil Physics, Academic Press, San Diego, Calif, USA, 1982.

[13] D. L. Nofziger, "Soil temperature changes with time and depth: theory," http://soilphysics.okstate.edu/software/SoilTemperature/document.pdf.

[14] B. R. Becker, A. Misra, and B. A. Fricke, "Development of correlations for soil thermal conductivity," International Communications in Heat and Mass Transfer, vol. 19, no. 1, pp. 59-68, 1992.

[15] Y. Chen, M. Shi, and X. Li, "Experimental investigation on heat, moisture and salt transfer in soil," International Communications in Heat and Mass Transfer, vol. 33, no. 9, pp. 1122-1129, 2006.

[16] M. Z. Yu, X. F. Peng, X. D. Li, and Z. H. Fang, "A simplified model for measuring thermal properties of deep ground soil," Experimental Heat Transfer, vol. 17, no. 2, pp. 119-130, 2004.

[17] J. Pfafferott, "Evaluation of earth-to-air heat exchangers with a standardised method to calculate energy efficiency," Energy and Buildings, vol. 35, no. 10, pp. 971-983, 2003.

[18] A. G. Kanaris, A. A. Mouza, and S. V. Paras, "Flow and heat transfer prediction in a corrugated plate heat exchanger using a CFD code," Chemical Engineering \& Technology, vol. 29, no. 8, pp. 923-930, 2006.

[19] Y. Wang, Q. Dong, and M. Liu, "Characteristics of fluid flow and heat transfer in shell side of heat exchangers with longitudinal flow of shell side fluid with different supporting structures," in Proceedings of the International Conference on Power Engineering, Hangzhou, China, October 2007.

[20] V. P. Sethi and S. K. Sharma, "Thermal modeling of a greenhouse integrated to an aquifer coupled cavity flow heat exchanger system," Solar Energy, vol. 81, no. 6, pp. 723-741, 2007.

[21] A. Shukla, G. N. Tiwari, and M. S. Sodha, "Thermal modeling for greenhouse heating by using thermal curtain and an earthair heat exchanger," Building and Environment, vol. 41, no. 7, pp. 843-850, 2006

[22] M. K. Ghosal, G. N. Tiwari, and N. S. L. Srivastava, “Thermal modeling of a greenhouse with an integrated earth to air heat exchanger: an experimental validation," Energy and Buildings, vol. 36, no. 3, pp. 219-227, 2004.

[23] J. Darkwa, G. Kokogiannakis, C. L. Magadzire, and K. Yuan, "Theoretical and practical evaluation of an earth-tube (E-tube) ventilation system," Energy and Buildings, vol. 43, no. 2-3, pp. 728-736, 2011.

[24] G. N. Tiwari, M. A. Akhtar, A. Shukla, and M. Emran Khan, "Annual thermal performance of greenhouse with an earth-air heat exchanger: an experimental validation," Renewable Energy, vol. 31, no. 15, pp. 2432-2446, 2006.
[25] M. K. Ghosal, G. N. Tiwari, D. K. Das, and K. P. Pandey, "Modeling and comparative thermal performance of ground air collector and earth air heat exchanger for heating of greenhouse," Energy and Buildings, vol. 37, no. 6, pp. 613-621, 2005.

[26] F. Al-Ajmi, D. L. Loveday, and V. I. Hanby, "The cooling potential of earth-air heat exchangers for domestic buildings in a desert climate," Building and Environment, vol. 41, no. 3, pp. 235-244, 2006.

[27] X. Li, J. Zhao, and Q. Zhou, "Inner heat source model with heat and moisture transfer in soil around the underground heat exchanger," Applied Thermal Engineering, vol. 25, no. 10, pp. 1565-1577, 2005.

[28] P. Hollmuller, "Analytical characterisation of amplitudedampening and phase-shifting in air/soil heat-exchangers," International Journal of Heat and Mass Transfer, vol. 46, no. 22, pp. 4303-4317, 2003.

[29] H. Wu, S. Wang, and D. Zhu, "Modelling and evaluation of cooling capacity of earth-air-pipe systems," Energy Conversion and Management, vol. 48, no. 5, pp. 1462-1471, 2007.

[30] K. H. Lee and R. K. Strand, "The cooling and heating potential of an earth tube system in buildings," Energy and Buildings, vol. 40, no. 4, pp. 486-494, 2008.

[31] A. Tzaferis, D. Liparakis, M. Santamouris, and A. Argiriou, "Analysis of the accuracy and sensitivity of eight models to predict the performance of earth-to-air heat exchangers," Energy and Buildings, vol. 18, no. 1, pp. 35-43, 1992.

[32] G. Mihalakakou, M. Santamouris, and D. Asimakopoulos, "Modelling the thermal performance of earth-to-air heat exchangers," Solar Energy, vol. 53, no. 3, pp. 301-305, 1994.

[33] M. Bojic, N. Trifunovic, G. Papadakis, and S. Kyritsis, "Numerical simulation, technical and economic evaluation of air-toearth heat exchanger coupled to a building," Energy, vol. 22, no. 12, pp. 1151-1158, 1997.

[34] C. Gauthier, M. Lacroix, and H. Bernier, "Numerical simulation of soil heat exchanger-storage systems for greenhouses," Solar Energy, vol. 60, no. 6, pp. 333-346, 1997.

[35] P. Hollmuller and B. Lachal, "Cooling and preheating with buried pipe systems: monitoring, simulation and economic aspects," Energy and Buildings, vol. 33, no. 5, pp. 509-518, 2001.

[36] V. P. Kabashnikov, L. N. Danilevskii, V. P. Nekrasov, and I. P. Vityaz, "Analytical and numerical investigation of the characteristics of a soil heat exchanger for ventilation systems," International Journal of Heat and Mass Transfer, vol. 45, no. 11, pp. 2407-2418, 2002.

[37] M. Santamouris, G. Mihalakakou, A. Argiriou, and D. N. Asimakopoulos, "On the performance of buildings coupled with earth to air heat exchangers," Solar Energy, vol. 54, no. 6, pp. 375-380, 1995.

[38] G. Mihalakakou, M. Santamouris, J. O. Lewis, and D. N. Asimakopoulos, "On the application of the energy balance equation to predict ground temperature profiles," Solar Energy, vol. 60, no. 3-4, pp. 181-190, 1997.

[39] H. Ben Jmaa Derbel and O. Kanoun, "Investigation of the ground thermal potential in tunisia focused towards heating and cooling applications," Applied Thermal Engineering, vol. 30, no. 10, pp. 1091-1100, 2010.

[40] N. M. Thanu, R. L. Sawhney, R. N. Khare, and D. Buddhi, "An experimental study of the thermal performance of an earth-airpipe system in single pass mode," Solar Energy, vol. 71, no. 6, pp. 353-364, 2001. 
[41] O. Ozgener, L. Ozgener, and J. W. Tester, "A practical approach to predict soil temperature variations for geothermal (ground) heat exchangers applications," International Journal of Heat and Mass Transfer, vol. 62, no. 1, pp. 473-480, 2013.

[42] H. Su, X.-B. Liu, L. Ji, and J.-Y. Mu, "A numerical model of a deeply buried air-earth-tunnel heat exchanger," Energy and Buildings, vol. 48, pp. 233-239, 2012.

[43] A. Sehli, A. Hasni, and M. Tamali, "The potential of earth-air heat exchangers for low energy cooling of buildings in South Algeria," Energy Procedia, vol. 18, pp. 496-506, 2012.

[44] R. Kumar, S. Ramesh, and S. C. Kaushik, "Performance evaluation and energy conservation potential of earth-air-tunnel system coupled with non-air-conditioned building," Building and Environment, vol. 38, no. 6, pp. 807-813, 2003.

[45] M. De Paepe and A. Janssens, "Thermo-hydraulic design of earth-air heat exchangers," Energy and Buildings, vol. 35, no. 4, pp. 389-397, 2003.

[46] M. Cucumo, S. Cucumo, L. Montoro, and A. Vulcano, "A onedimensional transient analytical model for earth-to-air heat exchangers, taking into account condensation phenomena and thermal perturbation from the upper free surface as well as around the buried pipes," International Journal of Heat and Mass Transfer, vol. 51, no. 3-4, pp. 506-516, 2008.

[47] A. De Jesus Freire, J. L. C. Alexandre, V. B. Silva, N. D. Couto, and A. Rouboa, "Compact buried pipes system analysis for indoor air conditioning," Applied Thermal Engineering, vol. 51, no. 1-2, pp. 1124-1134, 2013.

[48] G. Mihalakakou, M. Santamouris, D. Asimakopoulos, and I. Tselepidaki, "Parametric prediction of the buried pipes cooling potential for passive cooling applications," Solar Energy, vol. 55, no. 3, pp. 163-173, 1995.

[49] A. S. Dhaliwal and D. Y. Goswami, Heat Transfer Analysis Environment Control Using an Underground Air Tunnel, ASME Solar Energy Division, Las Vegas, Nev, USA, 1984.

[50] B. K. Shingari, "Earth tube heat exchanger," Poultry International, vol. 34, no. 14, pp. 92-97, 1995.

[51] V. Badescu, "Simple and accurate model for the ground heat exchanger of a passive house," Renewable Energy, vol. 32, no. 5, pp. 845-855, 2007.

[52] J. Zhao, H. Wang, X. Li, and C. Dai, "Experimental investigation and theoretical model of heat transfer of saturated soil around coaxial ground coupled heat exchanger," Applied Thermal Engineering, vol. 28, no. 2-3, pp. 116-125, 2008.

[53] P. Tittelein, G. Achard, and E. Wurtz, "Modelling earth-to-air heat exchanger behaviour with the convolutive response factors method," Applied Energy, vol. 86, no. 9, pp. 1683-1691, 2009.

[54] E. Ozden and I. Tari, "Shell side CFD analysis of a small shelland-tube heat exchanger," Energy Conversion and Management, vol. 51, no. 5, pp. 1004-1014, 2010.

[55] V. Bansal, R. Mishra, G. D. Agarwal, and J. Mathur, "Performance analysis of integrated earth-air-tunnel-evaporative cooling system in hot and dry climate," Energy and Buildings, vol. 47, pp. 525-532, 2012.

[56] V. Bansal, R. Misra, G. D. Agrawal, and J. Mathur, "Performance evaluation and economic analysis of integrated earth-air-tunnel heat exchanger-evaporative cooling system," Energy and Buildings, vol. 55, pp. 102-108, 2012.

[57] V. Bansal, R. Misra, G. D. Agarwal, and J. Mathur, “'Derating Factor' new concept for evaluating thermal performance of earth air tunnel heat exchanger: a transient CFD analysis," Applied Energy, vol. 102, pp. 418-426, 2013.
[58] R. Misra, V. Bansal, G. D. Agrawal, J. Mathur, and T. K. Aseri, "CFD analysis based parametric study of derating factor for Earth Air Tunnel Heat Exchanger," Applied Energy, vol. 103, pp. 266-277, 2013.

[59] V. Bansal, R. Misra, G. D. Agarwal, and J. Mathur, "Transient effect of soil thermal conductivity and duration of operation on performance of Earth Air Tunnel Heat Exchanger," Applied Energy, vol. 103, pp. 1-11, 2013.

[60] R. Kumar, A. R. Sinha, B. K. Singh, and U. Modhukalya, "A design optimization tool of earth-to-air heat exchanger using a genetic algorithm," Renewable Energy, vol. 33, no. 10, pp. 22822288, 2008.

[61] A. M. Gustafsson, L. Westerlund, and G. Hellström, "CFDmodelling of natural convection in a groundwater-filled borehole heat exchanger," Applied Thermal Engineering, vol. 30, no. 6-7, pp. 683-691, 2010.

[62] R. Al-Khoury, T. Kölbel, and R. Schramedei, "Efficient numerical modeling of borehole heat exchangers," Computers and Geosciences, vol. 36, no. 10, pp. 1301-1315, 2010.

[63] J. Vaz, M. A. Sattler, E. D. Dos Santos, and L. A. Isoldi, "Experimental and numerical analysis of an earth-air heat exchanger," Energy and Buildings, vol. 43, no. 9, pp. 2476-2482, 2011.

[64] T. Mnasri, R. B. Younès, A. Mazioud, and J. F. Durastanti, "FVM-BEM method based on the Green's function theory for the heat transfer problem in buried co-axial exchanger," Comptes Rendus-Mecanique, vol. 338, no. 4, pp. 220-229, 2010.

[65] V. Khalajzadeh, M. Farmahini-Farahani, and G. Heidarinejad, "A novel integrated system of ground heat exchanger and indirect evaporative cooler," Energy and Buildings, vol. 49, pp. 604-610, 2012.

[66] A. Flaga-Maryanczyka, J. Schnotale, J. Radon, and K. Was, "Experimental measurements and CFD simulation of a ground source heat exchanger operating at a cold climate for a passive house ventilation system," Energy and Buildings, vol. 68, pp. 562-570, 2014.

[67] L. Ramírez-Dávila, J. Xamán, J. Arce, G. Álvarez, and I. Hernández-Pérez, "Numerical study of earth-to-air heat exchanger for three different climates," Energy and Buildings, vol. 76, pp. 238-248, 2014.

[68] G. Mihalakakou, M. Santamouris, D. Asimakopoulos, and A. Argiriou, "On the ground temperature below buildings," Solar Energy, vol. 55, no. 5, pp. 355-362, 1995.

[69] G. Mihalakakou, "On the heating potential of a single buried pipe using deterministic and intelligent techniques," Renewable Energy, vol. 28, no. 6, pp. 917-927, 2003.

[70] H. Breesch, A. Bossaer, and A. Janssens, "Passive cooling in a low-energy office building," Solar Energy, vol. 79, no. 6, pp. 682696, 2005.

[71] V. Badescu and D. Isvoranu, "Pneumatic and thermal design procedure and analysis of earth-to-air heat exchangers of registry type," Applied Energy, vol. 88, no. 4, pp. 1266-1280, 2011. 


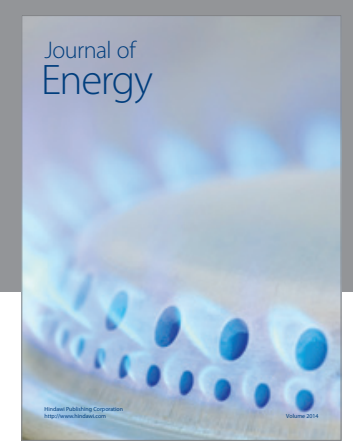

Journal of

Industrial Engineering
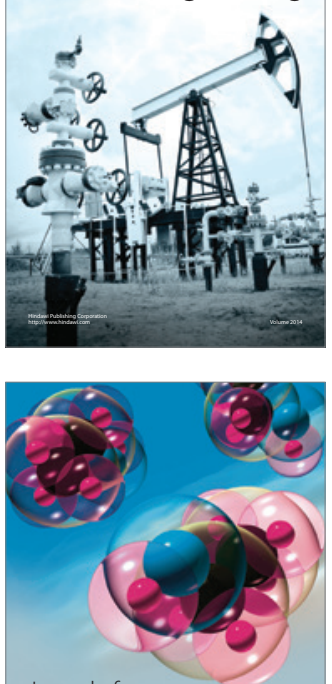

Fuels
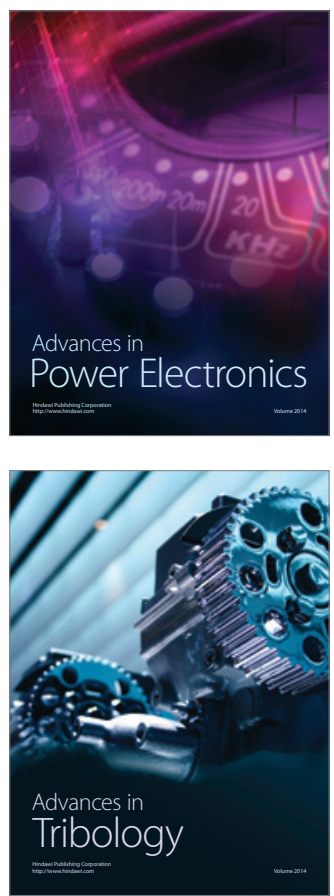

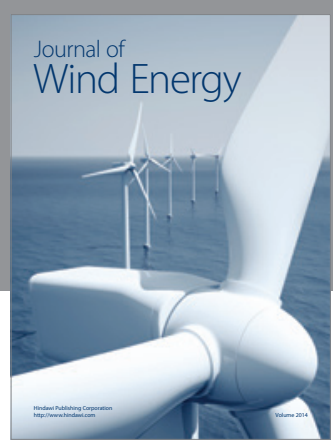

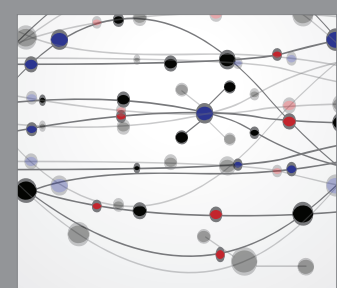

The Scientific World Journal

Submit your manuscripts at http://www.hindawi.com

Journal of

Structures


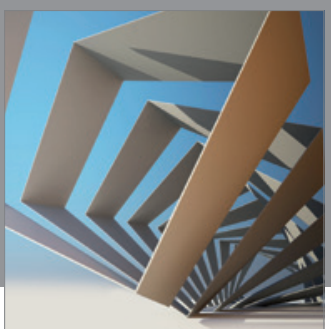

Rotating

Machinery
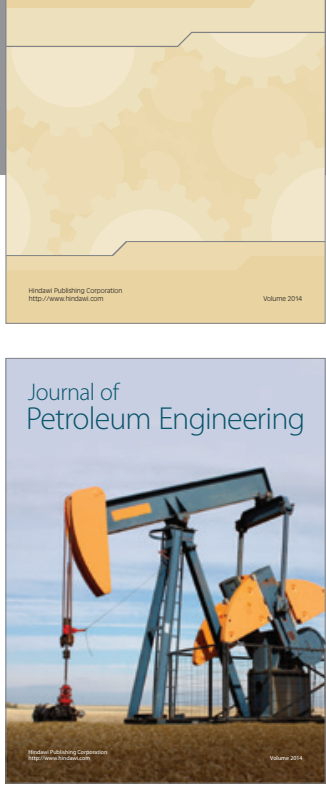

Journal of

Solar Energy
